\title{
Preclinical evaluation of a novel triple-acting PIM/PI3K/mTOR inhibitor, IBL-302, in breast cancer
}

\author{
Sean P. Kennedy $\mathbb{1}^{1} \cdot$ Michael $\mathrm{O}^{\prime} \mathrm{Neill}^{2} \cdot$ Darren Cunningham ${ }^{2} \cdot$ Patrick G. Morris $^{1,3} \cdot$ Sinead Toomey $^{1}$ • \\ Carmen Blanco-Aparicio $\mathbb{D}^{4} \cdot$ Sonia Martinez $\mathbb{C}^{4} \cdot$ Joaquin Pastor ${ }^{4}$ - Alex J. Eustace ${ }^{5} \cdot$ Bryan T. Hennessy $^{1,3,6}$
}

Received: 28 March 2019 / Revised: 20 January 2020 / Accepted: 30 January 2020 / Published online: 10 February 2020

(c) The Author(s) 2020. This article is published with open access

\begin{abstract}
The proviral integration of Moloney virus (PIM) family of protein kinases are overexpressed in many haematological and solid tumours. PIM kinase expression is elevated in PI3K inhibitor-treated breast cancer samples, suggesting a major resistance pathway for PI3K inhibitors in breast cancer, potentially limiting their clinical utility. IBL-302 is a novel molecule that inhibits both PIM and PI3K/AKT/mTOR signalling. We thus evaluated the preclinical activity of IBL-302, in a range of breast cancer models. Our results demonstrate in vitro efficacy of IBL-302 in a range of breast cancer cell lines, including lines with acquired resistance to trastuzumab and lapatinib. IBL-302 demonstrated single-agent, anti-tumour efficacy in suppression of pAKT, pmTOR and pBAD in the SKBR-3, BT-474 and HCC-1954 HER2+/PIK3CA-mutated cell lines. We have also shown the in vivo single-agent efficacy of IBL-302 in the subcutaneous BT-474 and HCC-1954 xenograft model in BALB/c nude mice. The combination of trastuzumab and IBL-302 significantly increased the anti-proliferative effect in HER2 + breast cancer cell line, and matched trastuzumab-resistant line, relative to testing either drug alone. We thus believe that the novel PIM and PI3K/mTOR inhibitor, IBL-302, represents an exciting new potential treatment option for breast cancer, and that it should be considered for clinical investigation.
\end{abstract}

These authors contributed equally: Alex J. Eustace, Bryan T. Hennessy

Supplementary information The online version of this article (https:// doi.org/10.1038/s41388-020-1202-y) contains supplementary material, which is available to authorized users.

Sean P. Kennedy

Seanpkennedy@rcsi.ie

1 Medical Oncology Group, Department of Molecular Medicine, Royal College of Surgeons Ireland, Smurfit Building Beaumont Hospital, Beaumont, Dublin, Ireland

2 Inflection Biosciences, Anglesea House, Blackrock, Dublin, Ireland

3 Cancer Clinical Trials and Research Unit, Beaumont Hospital, Dublin, Ireland

4 Experimental Therapeutics Programme, Spanish National Cancer Research Centre (CNIO), Madrid, Spain

5 Molecular Therapeutics for Cancer in Ireland, National Institute for Cellular Biotechnology, Dublin City University, Dublin, Ireland

6 Cancer Trials Ireland, Innovation House, Old Finglas Road, Botanic, Dublin, Ireland

\section{Introduction}

The PIM (proviral integration of Moloney virus) family of serine/threonine protein kinases were first discovered in experimental lymphomas [1]. The PIM kinase family is made up of three members; PIM 1, PIM 2 and PIM 3 [2]. Functions of the PIM kinase family vary, from cell cycle regulation, proliferation, apoptosis, invasion, metastasis and senescence $[3,4]$. PIM has been found to be overexpressed in clear-cell renal-cell carcinoma [5], head and neck carcinomas [6], prostate [7], testicular tumours [8] and several haematological and solid tumours [8-11]. Due to the potentially important role of the PIM kinase family in regulatory signalling pathways and increased expression levels across a variety of solid tumours, they have become attractive targets for therapeutic inhibition.

In recent years, there has been a growing number of publications highlighting the association of increased PIM 1 expression with poor clinical outcome in breast cancer [12-14]. The PIM kinase family has been indicated in sustaining activity of the PI3K/AKT/mTOR pathway through overlapping mechanisms [15]. The PI3K/AKT/ mTOR signalling pathway is integral to many aspects of regular cellular function, such as cell growth and survival. 
This signalling pathway is known to play a critical role in key aspects of carcinogenesis including increased genomic instability, decreased apoptosis, increased cellular proliferation and aberrant cytoskeleton alterations $[16,17]$.

There are overlapping mechanisms in the PIM and PI3K pathway, which ultimately regulate mTOR activation [18]. PIM kinases can attenuate pro-apoptotic signals such as BAD, p27 and p21 overlapping the PI3K pathway. PIM kinases can also regulate growth through continued activation of mTOR in parallel with the PI3K pathway [19]. Upregulation of PIM 1 expression has been shown in prostate cancer following inhibition of AKT [20], providing further evidence for the idea of crosstalk between both PIM kinase and PI3K/AKT/mTOR pathways [21]. Inhibition of AKT can also induce increased expression of several different receptor tyrosine kinases such as HER2 through PIM 1 -mediated regulation $[2,22]$.

IBL-302 is a first-in-class oral kinase inhibitor rationally designed to uniquely combine pan-PIM kinase, panPI3K and mTOR inhibition in a single agent. Currently, there are a number of different preclinical and phase I trials focused on PIM kinase inhibition [21, 23-29]; however, few have been successful, with a narrow therapeutic window, which resulted in a dose-limiting cardiac QTc prolongation (SGI-1776) [24] (NCT00848601) or other unintended off-target effects, resulting in lack of observed effect (AZD1208) [30] (NCT01588548). However, in combination with other inhibitors, preclinical and phase I clinical trials suggest more tolerability and higher efficacy for PIM kinase inhibitors [31, 32]. This suggests that IBL-302 may demonstrate ability as an anticancer agent. Indeed, IBL-302 has already shown efficacy in non-small-cell lung cancer, a number of solid tumour cell lines, including both oesophageal and prostate cancer cell lines [33, 34], and is currently being tested in both EGFR inhibitor-resistant lung and haematological, in vivo models of cancer [35].

The objective of this pre-clinical evaluation is to comprehensively determine and characterise the anti-tumour efficacy of IBL-302, in breast cancer models. Furthermore, we aim to elucidate whether there is a synergistic effect of IBL-302 and trastuzumab in breast cancer models, including in vitro models of trastuzumab resistance, given the published role of PI3K/AKT/mTOR, and more recently of PIM kinase signalling in trastuzumab resistance [36].

\section{Results}

\section{Effect of IBL-302 on breast cancer cell lines}

IBL-302 GI $_{50}$ values were determined via CellTiter-Glo anti-proliferation assay in a panel of 40 breast cancer cell lines. In Fig. 1 these cell lines are subdivided into their clinical and molecular subtypes, then ordered according to their $\mathrm{GI}_{50}$ value. The $\mathrm{GI}_{50}$ values for IBL-302 in the breast cancer cell lines ranged from $36 \mathrm{nM}$ (MDA-MB-361) to $2656 \mathrm{nM}$ (BT-483). There appear to be three plateaus of drug sensitivity: one at $<200 \mathrm{nM}$, one at $200-800 \mathrm{nM}$ and one at $>1000 \mathrm{nM}$. PIM 1, PIM 2 and PIM 3 mRNA expression values in each of the 40 breast cancer cell lines are also shown in Fig. 1.

Using the data in Fig. 1, we stratified the breast cancer cell lines based on their clinical subtype and mRNA expression profiles. We then examined their sensitivity to IBL-302 (Fig. 1). The results show that triple-negative breast cancer cell lines (TNBC) are more sensitive to IBL302 (Fig. 2a) than HER 2+/ER + breast cancer cell lines $(p<0.017)$. TNBC cell lines express more PIM 1 (Supplementary Fig. 1) when compared with HER2+/ER+ subtypes $(p<0.017)$. When subcategorising the TNBC cell lines further into Basal A and Basal B, the Basal A breast cancer subtype showed a significantly increased sensitivity to IBL-302 (Fig. 2b) when compared with the Basal B subtype $(p<0.033)$. When comparing PIM 1 mRNA expression versus IBL-302 $\mathrm{GI}_{50}$ values (Fig. 2c), there was a significant inverse correlation; in other words, increased PIM 1 expression was correlated with lower IBL-302 $\mathrm{GI}_{50}$ values $(p<0.016)$. Conversely, when comparing PIM 3 mRNA expression versus IBL-302 GI $_{50}$ values (Fig. 2d), there was a significant positive correlation; in other words, increased PIM 3 expression was correlated with increased IBL-302 $\mathrm{GI}_{50}$ values $(p<0.028)$. When the cell lines were divided via their therapeutic response to IBL-302 (responsive $=<400 \mathrm{nM}$ IBL-302 $\mathrm{IC}_{50}$ and non-responsive $=>400 \mathrm{nM}$ IBL-302 $\left.\mathrm{IC}_{50}\right)$, in cell lines that were responsive to IBL-302, there was higher PIM 1 expression, lower PIM 3 expression and lower levels of MYC amplification (Supplementary Fig. 2A-C). IBL-302 sensitivity correlates with higher PIM 1 expression in HER2+/ER+ cell lines, but not in TNBC cell lines (Supplementary Fig. 2D-I).

\section{PIM/AKT/PI3K inhibition and induction of apoptosis in breast cancer cell lines}

To demonstrate that IBL-302 was inhibiting its intended targets (PIM/AKT/PI3K), western blot analysis was utilised. Inhibition of pAKT-(S473) and pAKT-(T308) was assessed as a measure of PI3K inhibition [37-42], while pBAD-(S112) and pBAD-(S136) were assessed as a measure of PIM kinase inhibition (pBAD-(S136)/(S112) were utilised as a readout of PIM kinase activity as there are no reliable, commercial pPIM kinase antibodies available) [27, 43]; pmTOR-(S2448) and pmTOR(S2481) was also assessed as a measure of mTOR 
$\mathrm{IC}_{50}$ Breast Cancer Cell lines - IBL-302

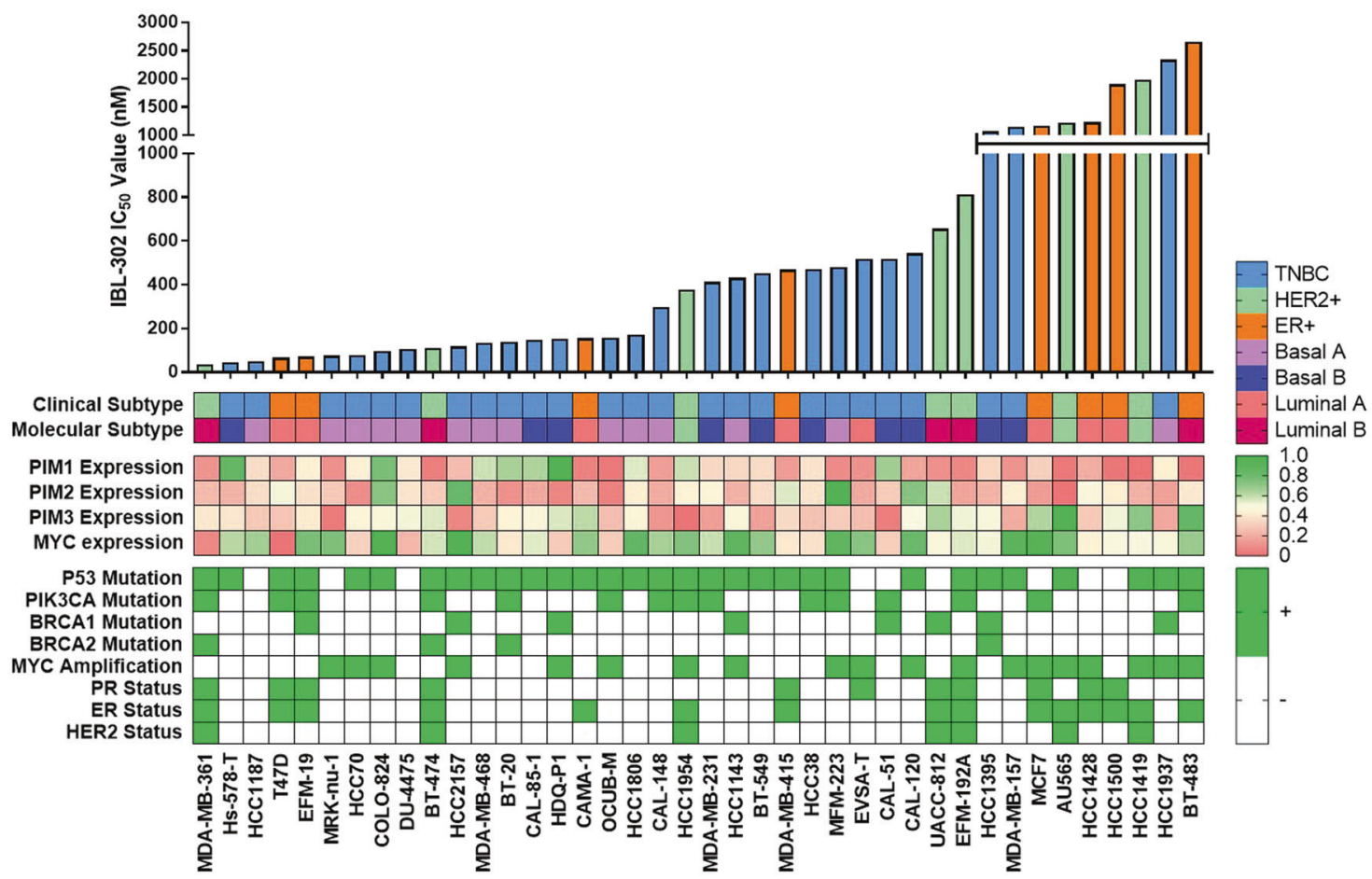

Fig. 1 IBL-302 was tested in a panel of 40 breast cancer cell lines using CellTiter-Glo anti-proliferation assay ( $72 \mathrm{~h}$ of incubation). The panel of 40 breast cancer cell lines are subdivided into their clinical and molecular subtypes: HER + (Green), ER+ (Orange) and
TNBC (Blue). Each cell line's corresponding PIM 1, PIM 2, PIM 3 and MYC expression levels, P53, PIK3CA, BRCA1 and BRCA2 mutation status, MYC amplification status and ER and PR status are displayed in Table 1.
Fig. 2 Using the clinical subtype, molecular subtype and PIM 1/3 expression values of 40 breast cancer cell lines, IBL-302 sensitivity (based on IC $_{50}$ ) was examined. (a) Compares triple-negative versus HER2-amplified/ER + breast cancer cell lines in terms of IBL302 IC $_{50}$ values. (b) Compares Basal A triple-negative with basal B triple-negative breast cancer cell lines in terms of IBL302 IC $_{50}$ values. (c) Compares PIM 1 expression across the 40 breast cancer cell lines with IBL$302 \mathrm{IC}_{50}$ values and (d) compares PIM 3 expression across the 40 breast cancer cell lines with IBL-302 $\mathrm{IC}_{50}$ values.
A

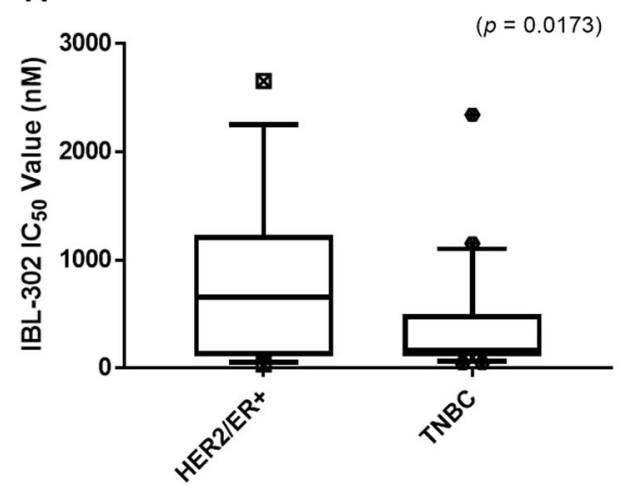

C

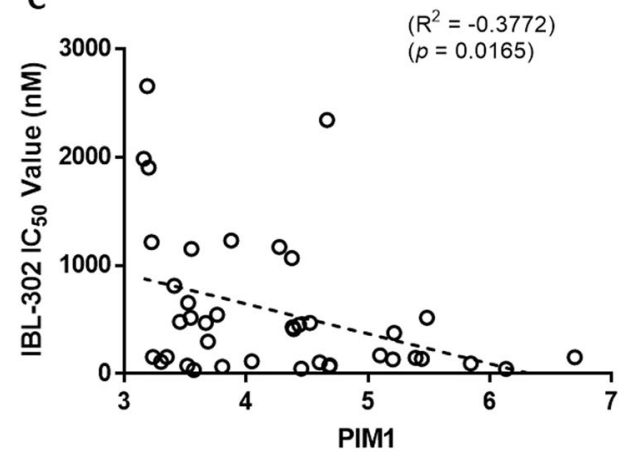

B

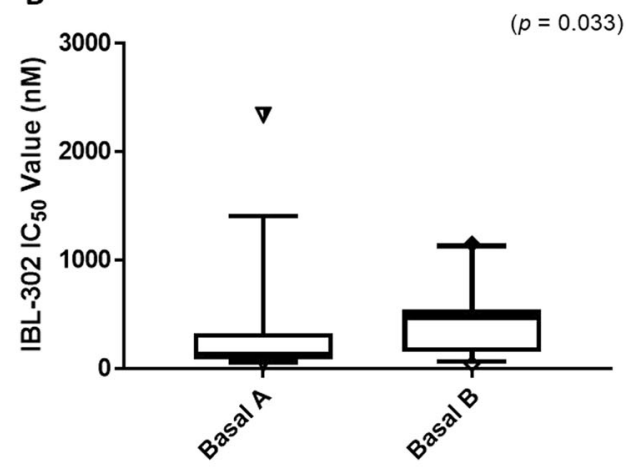

D

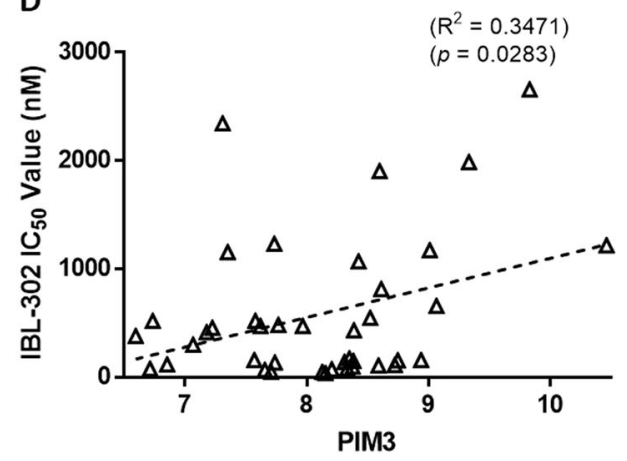




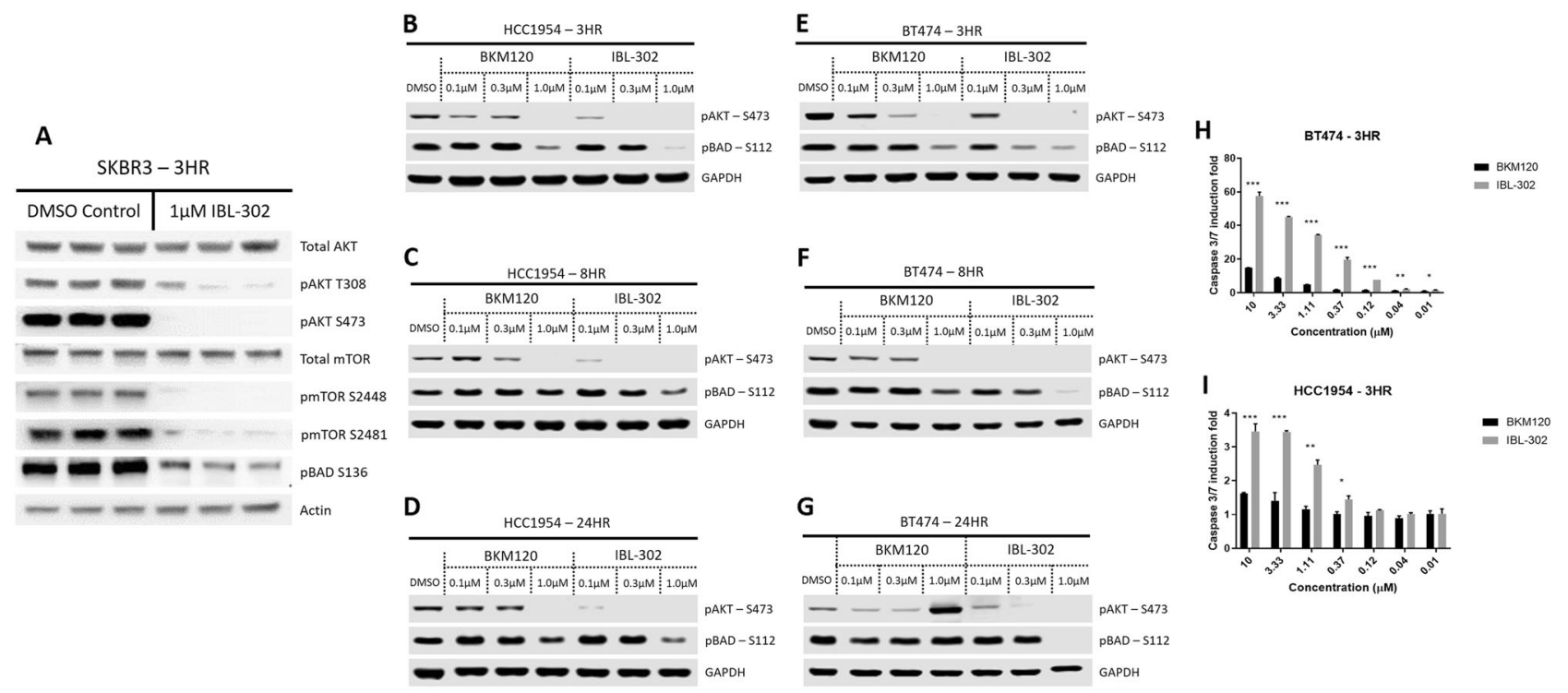

Fig. 3 Impact of IBL-302 on PIM/AKT/PI3K signalling components and induction of apoptosis in breast cancer cells. a SKBR-3 cells were treated with DMSO and IBL-302 $(1 \mu \mathrm{M})$ for $3 \mathrm{~h}$. The resulting total AKT, pAKT-(S473), pAKT-(T308), total mTOR, pmTOR-(S2448), pmTOR-(2481) and pBAD-(S138). b-g BT-474 and HCC-1954 cells were treated with ascending doses of BKM120 and

inhibition. Upon treatment with IBL-302 at $1 \mu \mathrm{M}$ for $3 \mathrm{~h}$, the levels of pAKT-(T308) $(p=0.049)$, pAKT-(s473) $(p=0.001), \quad$ pmTOR-(S2448) $\quad(p=0.001), \quad$ pmTOR$(\mathrm{S} 2481)(p=0.006)$ and pBAD-(S136) $(p=0.011)$ were all significantly reduced when compared with a DMSO control (Fig. 3a). Inhibition of both pAKTs, both pmTORs and pBAD highlights IBL-302's ability to inhibit the PI3K/mTOR and PIM pathways. Upon treatment with IBL-302 at $(0.1,0.3$ and $1 \mu \mathrm{M})$ for $(3,8$ and $24 \mathrm{~h})$, the levels of pAKT-(S473) and pBAD-(S112) were reduced in BT-474 and HCC-1954 (Fig. 3b-g). The effect of IBL302 on pAKT-S473 is observed at all concentrations in both BT-474 and HCC-1954, while only the highest concentration of BKM120 (pan-PI3K inhibitor) completely inhibits pAKT-(S473) phosphorylation. IBL-302 inhibited pBAD-(S112) at both 0.3 and $1 \mu \mathrm{M}$ concentrations of IBL-302 in BT-474 and HCC-1954 at the 3- and 8-h timepoints (Fig. 3b-g).

To determine whether IBL-302 induced death via apoptosis, a caspase $3 / 7$ induction assay was performed on both BT-474 and HCC-1954 cells for $3 \mathrm{~h}$ (Fig. 3h, i). There is a significant enhancement of apoptotic induction observed in Fig. 3h, i in both BT-474 and HCC-1954 over the 3-h incubation in both IBL-302 and BKM120 as the therapeutic concentration increases; however, IBL-302 induces significantly more activation of caspase $3 / 7$ when compared with BKM120 at similar concentrations (BT$474(p<0.0 .027)$ and HCC-1954 $(p<0.041))$.
IBL-302 $(0.1,0.3$ and $1 \mu \mathrm{M})$ for 3,8 and $24 \mathrm{~h}$. The resulting pAKT(S473) and pBAD-(S112) were analysed via western blot analysis. h, i BT-474 and HCC-1954 cells were treated with increasing doses of BKM120 and IBL-302 $(0-10 \mu \mathrm{M})$ for $3 \mathrm{~h}$. The resulting caspase $3 / 7$ induction was analysed via caspase assay.

The apoptotic effect of IBL-302 was further analysed on BT-474 and HCC-1954 cell lines via dual staining with annexin $\mathrm{V}$ and propidium iodide. BT-474 and BT-474-T cell lines were treated with IBL-302 alone $(1 \mu \mathrm{M})$, trastuzumab alone $(10 \mathrm{mg} / \mathrm{ml})$, or IBL-302+ trastuzumab $(1 \mu \mathrm{M} / 10 \mathrm{mg} / \mathrm{ml}$ ) for $72 \mathrm{~h}$ (Supplementary Figs. 3 and $4 \mathrm{~A}$, B). The results show that treatment with IBL-302 single agent or trastuzumab significantly induced cell apoptosis in BT-474-P, BT-474-T, HCC-1954-P and HCC-1954-L cell lines relative to untreated controls. The early apoptotic rates induced by the IBL-302 and trastuzumab combination was significantly higher than that of either IBL-302 or trastuzumab alone (Supplementary Figs. 3 and $4 \mathrm{~A}$, B) (BT-474-P $(p<0.003)$, BT-474-T $(p<0.001)$, HCC-1954-P $(p<0.001)$ and HCC-1954-L $(p<0.006))$.

\section{Efficacy of IBL-302 in breast cancer subcutaneous xenograft mouse models}

To evaluate the in vivo efficacy of IBL-302, we chose two cell lines, BT-474 (from the most sensitive group in vitro) and HCC-1954 (from the group of intermediate in vitro sensitivity) from Fig. 1. We examined the effect of IBL-302 in vivo using BT-474 and HCC-1954 subcutaneous xenografts in $\mathrm{BALB} / \mathrm{c}$ nude mice. The tumour volumes of the animals were plotted against time (days) (Fig. 4a, b). In the BT-474 xenograft study, in comparison with the vehicle control group, the IBL-302 $(50 \mathrm{mg} / \mathrm{kg})$ treated group 
demonstrated a highly significant reduction $(p<0.05)$ in the tumour volumes from day 12 to day 21 (Fig. 4a). There was an $8 \%$ bodyweight loss in the IBL-302- $(50 \mathrm{mg} / \mathrm{kg})$ treated group 10 days after the first treatment (Supplementary Fig. $5 \mathrm{~A}$ ), which was the reason for the introduction of the third treatment group in the xHCC1954 study. In this third group, vitamin $\mathrm{E}$ was included to prolong gut absorption of IBL302, while the overall IBL-302 dose was reduced to improve gastrointestinal tolerability of treatment. In the xHCC1954 xenograft study, in comparison to the vehicle control group, the IBL-302 $(50 \mathrm{mg} / \mathrm{kg})$ treated group demonstrated a significant reduction $(p<0.05)$ in tumour volumes from day 17 to day 24 after treatment initiation (Fig. 4b). However again, there was an $8 \%$ bodyweight loss in the IBL-302 $(50 \mathrm{mg} / \mathrm{kg})$ treated group starting at 10 days post 1st treatment (Supplementary Fig. 5B). This weight loss effect was essentially reversed in the dose-adjusted IBL-302-treated group in the xHCC1954 study (Supplementary Fig. 5B) (as described in 'Materials and methods' section) without a deleterious effect on the anti-tumour efficacy of IBL-302 (Fig. 4b).

\section{IBL-302 efficacy in trastuzumab and lapatinib- resistant breast cancer cell lines}

Given the published roles of PI3K/AKT/mTOR, and more recently of PIM kinase signalling in mediating resistance to HER2- targeted therapies [36], we evaluated IBL-302 in breast cancer models of acquired trastuzumab and lapatinib resistance. To examine the effect of IBL-302 used as a single agent, and in combination with trastuzumab, cell proliferation assays were employed in BT-474-P, BT-474-T, SKBR-3-P, SKBR-3-T, SKBR-3-L, HCC-1954-P and HCC-1954-L cell lines. These cell lines are defined in the methods with $\mathrm{P}$ representing the parental cell lines. IBL-302 performed well as a single agent in resistant cell lines, achieving $\mathrm{GI}_{50}$ values ranging from $33.4 \mathrm{~nm} \pm 2.9 \mathrm{~nm}$ in SKBR-3-T cell line to $165.22 \mathrm{~nm} \pm 17.1 \mathrm{~nm}$ in HHCC1954-L (Table 2).

Enhancement of the anti-proliferative efficacy was observed when IBL-302 and trastuzumab were combined across the seven breast cancer cell lines (Fig. 5a-g). In SKBR-3-P, SKBR-3-T and SSKBR3L cells, the combination of IBL-302 and trastuzumab was significantly more effective than either single agent alone (Fig. 5a-c). It was shown in SKBR-3-T cell line that $50 \mathrm{nM}$ IBL-302 $10 \mathrm{mg} / \mathrm{ml}$ trastuzumab combination was significantly more effective than either therapeutic alone $(p=0.002)$ (Fig. 5b). The trastuzumab sensitive BBT474-P and the resistant BBT474$\mathrm{T}$ cell lines both showed significantly more growth inhibition with the IBL-302 and trastuzumab combination when compared with each agent alone (Fig. 5d, e). Lastly, the intrinsically trastuzumab-resistant HCC-1954-P and HCC1954-L cell lines both showed significantly more growth
A

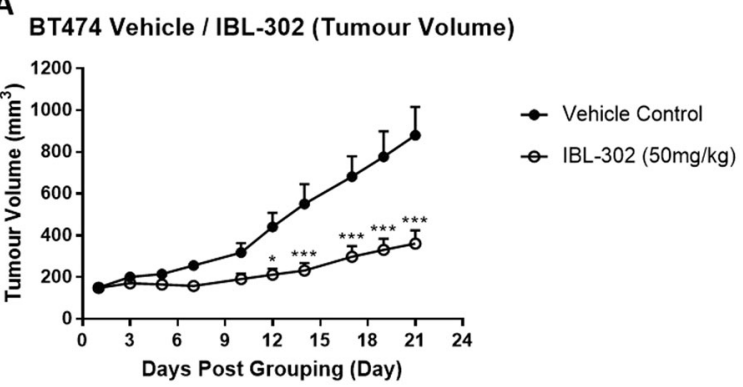

B

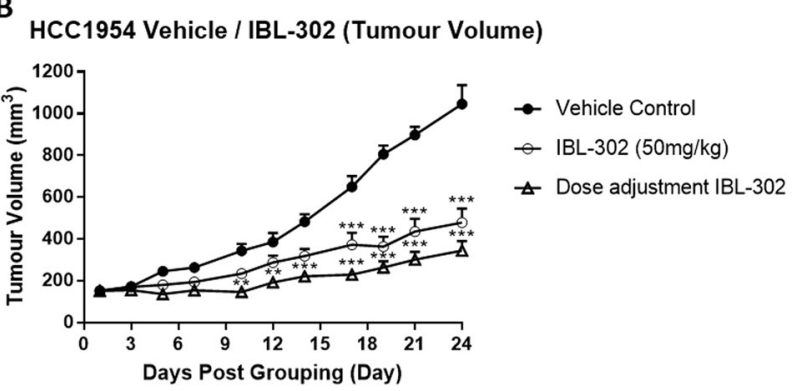

Fig. 4 In vivo efficacy of IBL-302 was determined in BT-474 and HCC-1954 subcutaneous xenograft models in BALB/c nude mice. a BT-474 xenograft mice were treated with vehicle control and IBL$302(50 \mathrm{mg} / \mathrm{kg}$ ). BT-474 tumour (mean $\pm \mathrm{SE}$ ) volumes were measure and plotted as a function of time. $P$ values were determined via Student $t$ test and $(p<0.05)$ was considered to be statistically significant. b HCC-1954 xenograft mice were treated with vehicle control, IBL$302(50 \mathrm{mg} / \mathrm{kg}$ ) and dose adjustment IBL-302 (as described in 'Materials and methods' section). HCC-1954 tumour (mean \pm SE) volumes were measured and plotted as a function of time. $P$ values were determined via Student $t$ test and $(p<0.05)$ was considered to be statistically significant.

inhibition with the combination of IBL-302 and trastuzumab compared with each therapeutic alone at most evaluated doses (Fig. 5f, g).

\section{Western blot analysis of IBL-302-treated BT-474 xenograft tumours}

Western blot analysis was also performed on tumour samples obtained from xenograft in vivo models of BT-474 $8 \mathrm{~h}$ and $24 \mathrm{~h}$ post the last dose with BKM120 $(35 \mathrm{mg} / \mathrm{kg})$ and IBL-302 $(50 \mathrm{mg} / \mathrm{kg})$. The effect of IBL-302 on pAKT(S473), pBAD-(S112) and PIM 1 was not significant when compared with either the vehicle control or BKM120treated tumour samples (Supplementary Fig. 6).

\section{Discussion}

PIM and PI3K kinases can mediate several of their cellular functions through subsequent phosphorylation of a variety of intersecting downstream signalling components. They are crucial to several cellular processes, including genomic 
Table 1 Determination of the average IBL-302 IC $_{50}$ value for each of the breast cancer cell lines listed after 120-h incubation. Each cell line's corresponding PIM 1, PIM 2, PIM 3 and MYC expression levels, PIK3CA and PTEN mutation status, MYC amplification status, and ER and PR status are displayed in the table.

IBL-302 single-agent expression data/statistics

\begin{tabular}{|c|c|c|c|c|c|c|c|c|c|c|}
\hline Cell line ID & $\begin{array}{l}\text { IBL-302 } \\
\mathrm{IC}_{50}(\mathrm{nM})\end{array}$ & $\begin{array}{l}\text { MYC } \\
\text { amplification }\end{array}$ & $\begin{array}{l}\text { MYC } \\
\text { expression }\end{array}$ & $\mathrm{PR}+$ & $\mathrm{ER}+$ & $\begin{array}{l}\text { PTEN } \\
\text { mutation }\end{array}$ & $\begin{array}{l}\text { PIM } 1 \\
\text { expression }\end{array}$ & $\begin{array}{l}\text { PIM } 2 \\
\text { expression }\end{array}$ & $\begin{array}{l}\text { PIM } 3 \\
\text { expression }\end{array}$ & $\begin{array}{l}\text { PI3K } \\
\text { mutation }\end{array}$ \\
\hline $\begin{array}{l}\text { MDA-MB- } \\
361\end{array}$ & 37 & No & 8.803 & Yes & Yes & No & 3.57 & 3.201 & 8.154 & Yes \\
\hline Hs-578-T & 45 & No & 10.865 & No & No & No & 6.133 & 3.172 & 8.128 & No \\
\hline HCC1187 & 49 & No & 11.031 & No & No & No & 4.453 & 3.377 & 7.708 & No \\
\hline $\mathrm{T} 47 \mathrm{D}$ & 65 & No & 8.512 & Yes & Yes & No & 3.803 & 3.586 & 7.657 & Yes \\
\hline EFM-19 & 70 & No & 11.42 & Yes & Yes & No & 4.682 & 3.396 & 8.206 & No \\
\hline MRK-nu-1 & 75 & Yes & 11.391 & No & No & No & 3.516 & 3.266 & 6.715 & No \\
\hline HCC70 & 79 & Yes & 9.758 & No & No & Yes & 4.686 & 2.983 & 8.332 & No \\
\hline COLO-824 & 96 & Yes & 12.354 & No & No & No & 5.843 & 3.884 & 8.376 & No \\
\hline DU-4475 & 106 & No & 9.401 & No & No & No & 4.604 & 3.413 & 8.591 & No \\
\hline BT-474 & 110 & No & 10.685 & Yes & Yes & No & 3.302 & 3.289 & 8.723 & Yes \\
\hline HCC2157 & 117 & Yes & 12.205 & No & No & No & 4.045 & 4.019 & 6.855 & No \\
\hline $\begin{array}{l}\text { MDA-MB- } \\
468\end{array}$ & 134 & No & 10.81 & No & No & Yes & 5.204 & 3.16 & 7.738 & No \\
\hline BT-20 & 138 & No & 10.056 & No & No & No & 5.441 & 3.002 & 8.309 & Yes \\
\hline CAL-85-1 & 148 & No & 10.601 & No & No & No & 5.391 & 3.114 & 8.383 & No \\
\hline HDQ-P1 & 154 & Yes & 9.654 & No & No & No & 6.697 & 2.947 & 8.747 & No \\
\hline CAMA-1 & 155 & No & 11.199 & No & Yes & Yes & 3.347 & 3.195 & 8.94 & No \\
\hline OCUB-M & 157 & Yes & 9.677 & No & No & No & 3.234 & 2.924 & 7.571 & Yes \\
\hline HCC1806 & 171 & No & 11.761 & No & No & No & 5.1 & 3.461 & 8.351 & No \\
\hline CAL-148 & 299 & No & 11.005 & No & No & Yes & 3.685 & 3.13 & 7.067 & No \\
\hline HCC-1954 & 379 & Yes & 11.339 & No & Yes & No & 5.215 & 3.479 & 6.596 & Yes \\
\hline $\begin{array}{l}\text { MDA-MB- } \\
231\end{array}$ & 413 & No & 10.754 & No & No & No & 4.389 & 3.493 & 7.178 & No \\
\hline HCC 1143 & 431 & Yes & 11.835 & No & No & No & 4.381 & 3.16 & 8.387 & No \\
\hline BT-549 & 454 & No & 11.172 & No & No & Yes & 4.434 & 3.374 & 7.225 & No \\
\hline $\begin{array}{l}\text { MDA-MB- } \\
415\end{array}$ & 470 & No & 10.057 & Yes & Yes & Yes & 3.668 & 3.64 & 7.967 & No \\
\hline HCC38 & 471 & No & 9.959 & No & No & No & 4.524 & 3.404 & 7.62 & No \\
\hline MFM-223 & 481 & Yes & 11.836 & No & No & No & 3.457 & 4.279 & 7.767 & Yes \\
\hline EVSA-T & 518 & Yes & 11.28 & Yes & No & Yes & 3.543 & 3.126 & 7.579 & No \\
\hline CAL-51 & 519 & No & 9.701 & No & No & Yes & 5.484 & 3.286 & 6.736 & Yes \\
\hline CAL-120 & 545 & Yes & 11.632 & No & No & No & 3.761 & 3.887 & 8.521 & No \\
\hline UACC-812 & 656 & No & 10.296 & Yes & Yes & No & 3.523 & 3.682 & 9.066 & No \\
\hline EFM-192A & 813 & Yes & 10.626 & Yes & Yes & No & 3.409 & 3.096 & 8.612 & Yes \\
\hline HCC1395 & 1068 & No & 10.488 & No & No & No & 4.374 & 3.167 & 8.425 & No \\
\hline $\begin{array}{l}\text { MDA-MB- } \\
157\end{array}$ & 1154 & Yes & 11.964 & No & No & No & 3.551 & 3.456 & 7.353 & No \\
\hline MCF7 & 1172 & Yes & 12.124 & Yes & Yes & No & 4.273 & 3.055 & 9.009 & Yes \\
\hline AU565 & 1216 & Yes & 11.405 & No & Yes & No & 3.223 & 2.852 & 10.46 & No \\
\hline HCC 1428 & 1232 & Yes & 10.198 & Yes & Yes & No & 3.877 & 3.525 & 7.735 & No \\
\hline HCC 1500 & 1903 & No & 10.375 & Yes & Yes & No & 3.199 & 3.46 & 8.598 & No \\
\hline HCC1419 & 1985 & Yes & 6.421 & No & Yes & No & 3.159 & 3.156 & 9.332 & No \\
\hline HCC1937 & 2343 & Yes & 10.301 & No & No & No & 4.664 & 3.081 & 7.309 & No \\
\hline BT-483 & 2657 & Yes & 11.105 & No & Yes & No & 3.188 & 3.436 & 9.829 & Yes \\
\hline
\end{tabular}


Table 2 Determination of the average IBL-302 $\mathrm{IC}_{50}$ value for each of the breast cancer cell lines listed after 120-h incubation. Results are mean \pm $\mathrm{SD}$ values for three independent experiments.

\begin{tabular}{llllllll}
\hline IBL-302 single-agent $\mathrm{IC}_{50}$ panel & & & & \\
\hline Cell line ID & SKBR-3-P & SKBR-3-T & SKBR-3-L & BT-474-P & BT-474-T & HCC-1954-P & HCC-1954-L \\
\hline Average $\mathrm{IC}_{50}(\mathrm{nM})$ & $76.1 \pm 8.9$ & $33.4 \pm 2.9$ & $136.6 \pm 35.2$ & $91.2 \pm 2.1$ & $66.1 \pm 1.3$ & $144.6 \pm 8.9$ & $165.2 \pm 17.1$ \\
\hline
\end{tabular}

A

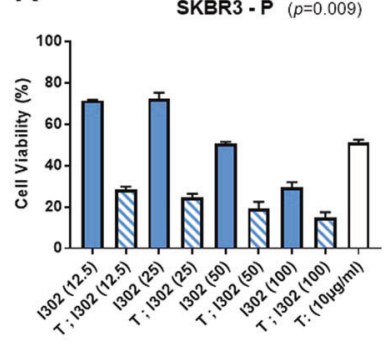

D

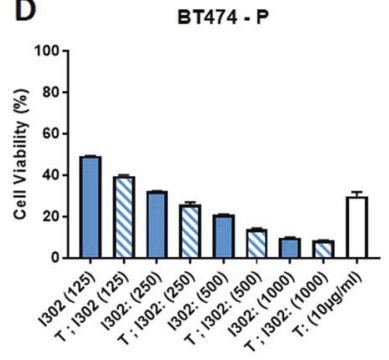

B

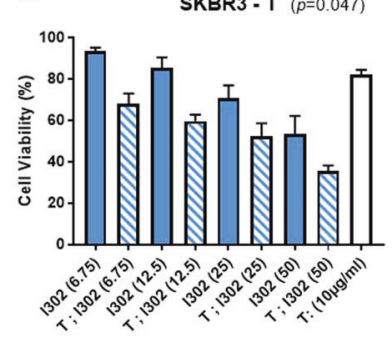

E

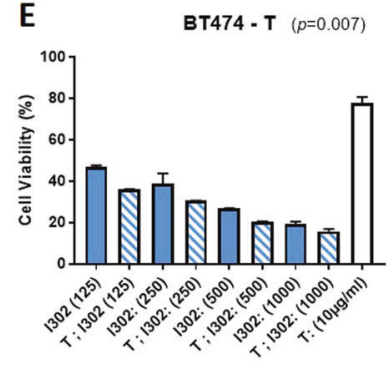

Fig. 5 Acid phosphatase assay showing the efficacy of IBL-302 on viability in trastuzumab and lapatinib resistant breast cancer cells. a SKBR-3 trastuzumab-resistant (SKBR-3-T) and (b) SKBR-3 lapatinib-resistant (SKBR-3-L) cells. c BT-474 parental (BT-474-P) and (d) BT-474 trastuzumab resistant (BT-474-T). e HCC-1954 parental

instability (e.g., through an interaction between PIM 1 and NUMA [7, 44]), cell cycle regulation (e.g., through PIM 1 phosphorylation of p21waf1 [45, 46]) and induction of senescence (e.g., through overexpression of PIM 1 [47-49]). Considering the overlapping effect of these kinases on normal and cancerous cellular function, an inhibitor that targets both the PIM and the PI3K/AKT/ mTOR pathway would have potential utility in cancer treatment.

In this study, the pan-PIM, PI3K and mTOR inhibitor, IBL-302, demonstrated efficacy across 40 breast cancer cell lines with $\mathrm{GI}_{50} \mathrm{~s}$ ranging from $36 \mathrm{nM}$ (MDA-MB-361) to $2656 \mathrm{nM}$ (BT-483). IBL-302 has been shown to inhibit $\mathrm{PI} 3 \mathrm{~K} \alpha(2.08 \mathrm{nM})$ to roughly the same degree of efficacy as PIM 2 (7.74 nM) and PIM 3 (5.86 nM), while IBL-302 has been shown to have lower efficacy against mTOR $(81.3 \mathrm{nM})$ and PIM $1(22.8 \mathrm{nM})$ [50]. Stratifying the 40 breast cancer cell lines into subtype showed that TNBC cell lines were most sensitive to IBL-302 $(p<0.017)$ (Fig. 2a). The TNBC cell lines also had significantly increased levels of PIM 1 when compared with the HER2+ and ER+ cell
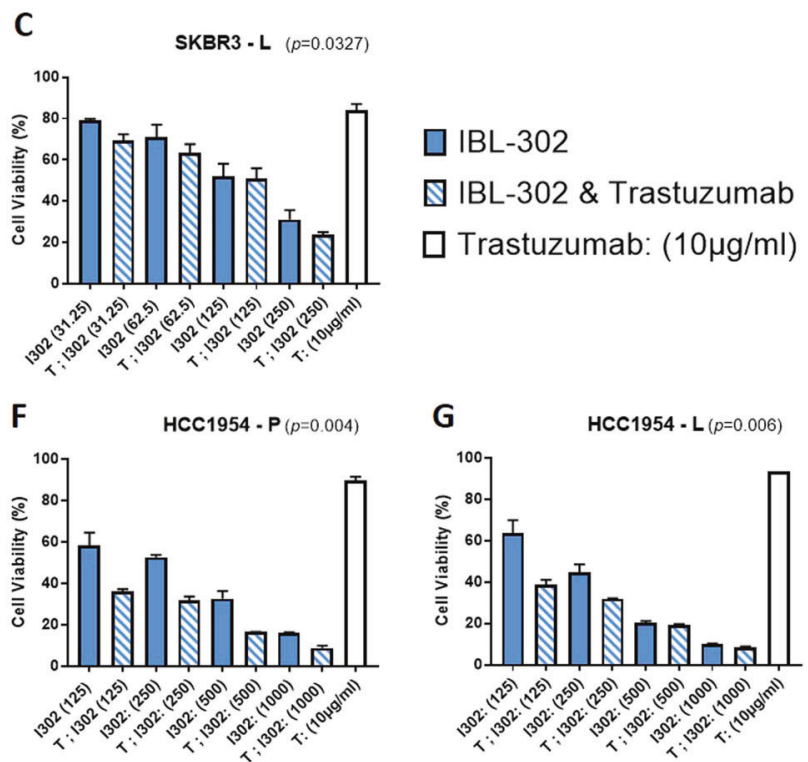

(HCC-1954-P) and (f) HCC-1954 lapatinib-resistant (HCC-1954-L) (g) cells after the combination of ascending amounts of IBL-302 (nM) with a static amount of trastuzumab $(10 \mu \mathrm{g} / \mathrm{ml})$. Significance was determined via Kruskal-Wallis, non-parametric test through utilisation of Prism software $(*>0.05)(* *>0.01)(* * *>0.001)$.

lines $(p<0.01)$ (Supplementary Fig. 1). This has already been described by Brasó-Maristany et al. and others who identified increased PIM 1 expression in TNBC that correlated with increased proliferation and protection from apoptosis [12, 51].

When the 40 breast cancer cell lines were stratified via their PIM 1 expression, an increased PIM 1 expression level was correlated $(p<0.016)$ (Fig. 2c) with decreased IBL-302 $\mathrm{GI}_{50}$ value, while an increased PIM 3 expression level was correlated $(p<0.028)$ (Fig. 2d) with increased IBL-302 GI 50 values. When the 40 breast cancer cell lines were stratified into HER2+/ER + and TNBC groups and then stratified again via their therapeutic response to IBL-302, it was shown in the responsive groups that PIM 1 expression was elevated, PIM 3 expression was decreased and MYC amplification significantly reduced when compared with the non-responsive groups (Supplementary Fig. 2A-C). These findings suggest that IBL-302 sensitivity in cell lines, may be differentially affected by PIM 1 expression versus PIM 3 expression. There have been studies to suggest that PIM 3 plays an overall protective role in cells via protection 
against apoptosis and increased proliferation [52]. Increased levels of PIM 3 have also been previously shown to indicate poor prognosis and indicate minimal response to chemotherapy [53]. The roles of expression PIM 1 as predictors of response to IBL-302 require further exploration. The increased expression of PIM 1 in both TNBC and HER2+ cell lines, along with the correlation between IBL-302 sensitivity and elevated PIM 1 expression, also suggests the potential for further study of IBL-302 in TNBC and HER2 + cell lines.

Inhibition of PI3K/AKT can promote increased expression of both PIM 1 [20] and HER2 [22] among other compensatory pathways that can mediate resistance to PI3K/AKT inhibitors [54-56]. Other studies have demonstrated that PIM 1-3 are able to inhibit BAD-induced apoptosis and prevent therapeutic rescue [36]. This provides further rationale for the combination of the dual PI3K/PIM inhibitor IBL-302 with trastuzumab in an effort to overcome trastuzumab resistance. The synergistic, anti-proliferative effect that we have demonstrated of IBL-302 in combination with trastuzumab, across 7 HER2 + cell lines supports this rationale (Fig. 5a-g). This combinatorial effect of IBL302 and trastuzumab was also prevalent in apoptotic readout when comparing both BT-474-P and BT-474-T cell lines (Supplementary Fig. 3A, B) and in HCC-1954-P and HCC-1954-L cell lines (Supplementary Fig. 4A, B). Our in vivo assessment of IBL-302 in subcutaneous xenograft models also shows that the PIM/PI3K/mTOR inhibitor, IBL-302, is effective in in vivo models of HER2+ breast cancer. Others have also shown that the targeting of PIM kinases with pan-PIM inhibitors can resensitise resistant models of disease, to other therapeutics $[12,57]$. These data reinforce the current consensus, that the role of targeting PIM kinases to rescue sensitivity to some anticancer therapies should be further explored [57-59].

In this study, we have determined that elevated expression of PIM 1 is significantly associated with elevated sensitivity to IBL-302 in both TNBC and HER2+/ER + cell lines. PIM 1 has been highlighted as a therapeutic target in TNBC $[12,14,60]$ and as a result, not much focus has been placed on HER2+/ER + cells, especially those with acquired resistance to HER2 targeted therapies. Interestingly, there is high PIM 1 expression in the HER2 + HCC1954 cells, whilst the PIK3CA mutant BT-474 cells, which have low expression of PIM 1, are also sensitive to IBL302. IBL-302 is a (PIM/PI3K/mTOR) inhibitor, so it maintains the potential to be therapeutically active in a cell line with high PIM 1 (like HCC-1954) and alternatively a cell line with mutant PIK3CA (BT-474) giving it a wider scope of use.

In recent studies with Copanlisib (a pan-PI3K inhibitor), it has been shown to be effective in advanced models of HER2 + breast cancer [61, 62]. Copanlisib has also demonstrated a preclinical and clinical benefit in women with trastuzumab refractor- advanced HER2 + breast cancer [61, 62]. The PI3K inhibitors utilised in these studies showed a cytostatic and not a cytotoxic effect. IBL-302 has demonstrated an ability to induce apoptosis individually and when combined with trastuzumab, potentially overcoming the limitation of current PI3K inhibitors (Fig. 3) (Supplementary Figs. 3, 4).

As referenced to in the introduction, there are several preclinical single-agent PIM kinase inhibitors available, but only a few have proceeded to phase I clinical trials, and been unsuccessful due to either a dose-limiting cardiac QTc prolongation (SGI-1776) [24] (NCT00848601) or lack of observed effect (AZD1208 in AML) [30, 57] (NCT01489722). As discussed earlier, PIM inhibitors in combination with another therapy may offer more promise. The pan-PIM kinase inhibitor, PIM447, is being tested in combination with Ruxotilinib, a JAK1/2 inhibitor in myelofibrosis [63] (NCT02370706). PIM447 (a pan-PIM kinase inhibitor) is being tested with BYL719 (a selective PI3K $\alpha$ inhibitor) in multiple myeloma (NCT02144038). AZD1897 (pan-PIM kinase inhibitor) and AZD5363 (AKT inhibitor) in combination are being investigated in leukaemia [31, 32]. Thus, we have chosen to evaluate the preclinical efficacy of the novel dual PIM and PI3K/mTOR inhibitor, IBL-302 in breast cancer as described herein.

Overall, considering the encouraging evidence surrounding PIM kinase inhibitors in combination with other inhibitors in cancer therapy [31, 32, 63], and evidence suggesting targeting multiple pathways simultaneously will rescue sensitivity $[18,20,22,51]$, as well as the in vitro and in vivo studies of IBL-302 in preclinical breast cancer models presented in this paper, we believe that the dual PI3K/mTOR and PIM inhibitor IBL-302 should be investigated further in breast cancer. We thus plan, to take the compound to phase I clinical trial evaluation in heavily pretreated breast cancer patients.

\section{Materials and methods}

\section{CellTiter-Glo assay}

The CellTiter-Glo screen was performed by Genomics of Drug Sensitivity in Cancer (GDSC) in the Wellcome Trust Sanger Institute, Hinxton UK. The drug screen took place over 2 equivalent sets of GDSC cell lines with 40 cells lines in total. The cell lines were seeded into 1536 well plates using an XRD-384 (Fluid-X) reagent dispenser. The number of cells seeded has been individually optimised for each cell line. IBL-302 was screened using a 7-pt dose response curve and a half-log (3.16-fold) dilution series. The dosing of the compounds was carried out using an ECHO 555 
(Labcyte) acoustic dispenser, and the duration of drug treatment is $72 \mathrm{~h}$. Cell number was measured using CellTiter-Glo (Promega) reagent. Cell lines were screened in RPMI-1640 media (Sigma) supplemented with 10\% FCS and DMEM/F12 media (Sigma) supplemented with $10 \%$ FCS, both maintained at $37^{\circ} \mathrm{C}$ with $5 \% \mathrm{CO}_{2}$.

\section{Cell culture}

Human HER2-amplified breast cancer cell lines were obtained from the Dublin City University (National Institute for Cellular Biotechnology) (DCU). Resistant variants were developed by continuous growth in relevant drug (SKBR-3 trastuzumab resistant (SKBR-3-T) (DCU): $100 \mu \mathrm{g} / \mathrm{ml}$ trastuzumab; SKBR-3 lapatinib resistant (SKBR-3-L) (DCU): $1000 \mathrm{nM}$ lapatinib; HCC-1954 lapatinib resistant (HCC1954-L) (DCU): $1000 \mathrm{nM}$ lapatinib; BT-474 trastuzumab resistant (BT-474-T) (DCU): $100 \mu \mathrm{g} / \mathrm{ml}$ trastuzumab) for 6 months, with drug refreshed twice weekly [64, 65]. All cell lines were grown in RPMI-1640 media (Sigma) supplemented with $10 \%$ FCS and maintained at $37{ }^{\circ} \mathrm{C}$ with $5 \%$ $\mathrm{CO}_{2}$. Cell line identity was confirmed by DNA fingerprinting, which was performed by Source Biosciences ${ }^{\mathrm{TM}}$. Cell lines were Mycoplasma tested before and after the in vitro experiments. trastuzumab $(21 \mathrm{mg} / \mathrm{ml})$ was obtained from Beaumont Hospital and prepared in bacteriostatic water. IBL-302 was supplied by Inflection Biosciences and stock solutions prepared in dimethyl sulfoxide (DMSO) at $10 \mathrm{mM}$ concentrations. BKM120 was supplied by Inflection Biosciences and stock solutions prepared in DMSO at $10 \mathrm{mM}$ concentrations.

\section{Western blot analysis}

To study the effect of IBL-302 on PI3K/AKT/mTOR and PIM kinase signalling, two breast cancer cell lines (BT-474 and HCC-1954) were treated with $0.1,0.3$ and $1 \mu \mathrm{M}$ IBL302 or BKM120 for 3, 8 and $24 \mathrm{~h}$. SKBR-3 cells were also utilised for western blot analysis, and treated with $1 \mu \mathrm{M}$ IBL-302 for $3 \mathrm{~h}$. BT-474 and HCC-1954 Cells were treated and then lysed with $1 \times$ complete lysis buffer for $15 \mathrm{~min}$ at $4{ }^{\circ} \mathrm{C}$ and the lysate was then centrifuged at $13,000 \mathrm{rpm}$ for $20 \mathrm{~min}$ at $4{ }^{\circ} \mathrm{C}$. Supernatant was collected for protein quantification using a BCA kit. A total of $20 \mu \mathrm{g}$ of sample per lane was loaded to a NuPAGE Novex 4-12\% Bis-Tris protein gel and resolved. The protein was then transferred using the Invitrogen iBlot 2 gel transfer device and the nitrocellulose transfer stacks. The membrane was blocked for $1 \mathrm{~h}$ in 5\% BSA at room temperature. The membrane was then incubated in primary antibodies (pAKT)-(S473) (CST, Cat No. 4060), pBAD-(S112) (CST, Cat No. 5284) and (GAPDH (Millipore, Cat No. MAB374) 1:5000) overnight at $4{ }^{\circ} \mathrm{C}$. The membrane was then washed thrice and incubated with secondary antibodies (LI-COR Biosciences, Cat No. 926-32213 and Cat No. 926-68072) (1:10,000 dilution) for $1 \mathrm{~h}$ at room temperature. Image was captured on Li-Cor Odyssey imager and proteins were quantified. SKBR-3 cell lines were treated with $1 \mu \mathrm{M}$ IBL-302 for $3 \mathrm{~h}$ and cells were treated and then lysed with $1 \times$ complete lysis buffer for $15 \mathrm{~min}$ at $4{ }^{\circ} \mathrm{C}$ and the lysate was then centrifuged at $15,000 \mathrm{rpm}$ for $10 \mathrm{~min}$ at $4{ }^{\circ} \mathrm{C}$. Supernatant was collected and protein quantified using a BCA assay. A total of $20 \mu \mathrm{g}$ of sample per lane was loaded to a mini-PROTEAN ${ }^{\circledR}$ TGX 4-15\% Bis-Tris protein gel and resolved. The protein was then transferred using the mini-PROTEAN ${ }^{\circledR}$ three-chamber wet transfer device and the nitrocellulose transfer stacks. The membrane was blocked for $1 \mathrm{~h}$ in $5 \%$ BSA at room temperature. The membrane was then incubated in primary antibodies (AKT) (CST, Cat No. 9272 S), (pAKT-T308) (CST, Cat No. 9275 S), (pAKT-S473) (CST, Cat No. 4060), (mTOR) (CST, Cat No. 2972 S), (pmTOR-S2448) (CST, Cat No. 2971 S), (pBAD)-(S136) (CST, Cat No. 9295) and (actin) (Sigma, Cat No. A5316) at a 1:1000 dilution overnight at $4{ }^{\circ} \mathrm{C}$. The membrane was then washed thrice and incubated with secondary antibodies (1:5000 dilution) for $1 \mathrm{~h}$ at room temperature. Image was captured on Li-Cor Odyssey imager and proteins were quantified. Western blot densitometry measurements were obtained via imageJ analysis and significance was determined using a student's $t$ test, as compared with the untreated DMSO controls. (* $\leq$ $0.05)(* * \leq 0.01)(* * * \leq 0.001)$ (Supplementary Fig. 7).

\section{Apoptosis assays}

To study the effect of IBL-302 on caspase 3/7 induction, two breast cancer cell lines (BT-474 and HCC-1954) were treated with increasing concentrations of IBL-302 $(0.01-10 \mu \mathrm{M})$ for $4 \mathrm{~h}$. Cells were seeded into a $96-$ well plate at 3000 cells per well for HCC-1954 and 12,000 cells per well for BT-474. Working solutions were prepared at 1:3 dilutions of $10 \mu \mathrm{M}$ IBL-302 descending along ten points. The cells were seeded on day 1 and day $2,0.5 \mu \mathrm{l}$ of compound solution was transferred to each of the cell plate wells containing $100 \mu \mathrm{l}$ of media. The plates were incubated with IBL-302 for $4 \mathrm{~h}$ at $5 \%$ $\mathrm{CO}_{2}, 37^{\circ} \mathrm{C}$. The Caspase-Glo buffer was thawed by equilibrating to room temperature. The lyophilised Caspase-Glo $3 / 7$ substrate was also equilibrated to room- temperature use. The Caspase-Glo 3/7 buffer and substrate were mixed to form the Caspase-Glo 3/7 reagent. After a 4-h IBL-302 incubation, addition of $100 \mu$ of Caspase-Glo 3/7 Reagent is following by mixing on an orbital shaker for $10 \mathrm{~min}$. The plate was allowed for $1 \mathrm{~h}$ to stabilise the luminescent signal and come to room temperature. The resulting luminescence was read at $500 \mathrm{nM}$ on a plate reader.

To determine the stages of apoptosis (Early versus Late), both BT-474 and HCC-1954 cell lines, were treated with 
$1 \mu \mathrm{M}$ IBL-302, $10 \mu \mathrm{g} / \mathrm{ml}$ trastuzumab and a combination of $1 \mu \mathrm{M}$ IBL-302/10 $\mu \mathrm{g} / \mathrm{ml}$ trastuzumab for $72 \mathrm{~h}$. Cells were seeded into a six-well plate at 500,000 cells per well. The cells were seeded on day 1 and day 2, $1 \mu \mathrm{M}$ IBL-302 was constituted in $1 \mathrm{ml}$ of RPMI-1640, $10 \mathrm{ug} / \mathrm{ml}$ trastuzumab in $1 \mathrm{ml}$ of RPMI-1640 and the combination of $1 \mu \mathrm{M}$ IBL-302/ $10 \mathrm{ug} / \mathrm{ml}$ trastuzumab in $1 \mathrm{ml}$ of RPMI-1640 and each corresponding wells media replaced with the treatment. After $72 \mathrm{~h}$ of treatment, the cells were detached using Trypsin, and washed twice with cold PBS before being exposed to Alexa Fluor ${ }^{\odot} 488$ annexin V $(5 \mu \mathrm{l})$ and $1 \mu \mathrm{l}$ of $100 \mu \mathrm{g} / \mathrm{ml}$ propidium iodide diluted in $100 \mu \mathrm{l}$ of annexinbinding buffer and incubated at room temperature for $20 \mathrm{~min}$. After incubation cells were mixed with an additional $400 \mu$ l of annexin-binding buffer. The cells were then analysed via flow cytometry, measuring the fluorescence emission at 520 and $575 \mathrm{~nm}$ using a 488-nm excitation. Early apoptosis cell population were marked with Annexin V and the absence of propidium iodide (Q3), while late apoptosis was indicated by double staining of both annexin $\mathrm{V}$ and propidium iodide (Q2).

\section{Proliferation assays}

For all resistant cell lines, drug was removed from the cells at least 7 days prior to starting assays, and no penicillin/ streptomycin was added to media during proliferation assays; $5 \times 10^{4}$ cells were seeded in 96-well plates. Plates are incubated overnight at $37^{\circ} \mathrm{C}$ to allow cells to adhere. Therapeutics were added at the same time, to the plates at specific concentrations and incubated at $37^{\circ} \mathrm{C}$. Following 5day incubation, during which control cells attained 80-90\% confluence, all media was removed from the plates and washed once with PBS. Proliferation was measured using the acid phosphatase assay as previously described [66].

\section{In vivo anti-tumour efficacy}

The in vivo animal experiments were carried out by ChemPartner ${ }^{(}$company of Shanghai, China, and were composed of two independent studies of IBL-302. The first was a BT-474 xenograft model and second, a HCC-1954 xenograft model.

\section{BT-474 xenograft model}

In the first study, 16 female nude mice (BALB/c nude mice), aged 6-8 weeks (about 18-20 g bodyweight), were implanted subcutaneously with a $0.5 \mathrm{mg}$ Estradiol pellet 2 days prior to cell inoculation. The mice were inoculated subcutaneously at the right flank with xBT474 tumour cells $\left(1 \times 10^{7}\right.$ cells/mouse) in $0.2-\mathrm{ml}$ mixture of the base media with $50 \%$ matrigel to promote tumour growth. The animals were randomly divided into four groups with four in each group as follows; a vehicle control group (10\% DMSO + 90\% PEG400) $8 \mathrm{~h}$ and $24 \mathrm{~h}$ post the last dose, as well as an IBL-302 group (50 mg/kg) (10\% DMSO + 90\% PEG400) $8 \mathrm{~h}$ and $24 \mathrm{~h}$ post the last dose. Each of the groups was orally gavaged for the full 21 days at $(50 \mathrm{mg} / \mathrm{kg} /$ day $)$. The tumour size was measured three times a week, in two dimensions using a calliper and the volume expressed in $\mathrm{mm}^{3}$. The tumour volume was calculated using the formula: $V=\left(0.5 \times A \times B^{2}\right)$ where $A$ and $B$ were the long and short diameters of the tumour, respectively. The mice were sacrificed at the end of the experiment and fresh tumour tissues were collected.

\section{HCC-1954 xenograft model}

In the second study, 24 female nude mice (BALB/c nude mice), aged 6-8 weeks (about $18-20 \mathrm{~g}$ of bodyweight), were implanted subcutaneously with a $0.5-\mathrm{mg}$ Estradiol pellet 2 days prior to cell inoculation. The mice were inoculated subcutaneously at the right flank with xHCC1954 tumour cells $\left(5 \times 10^{6}\right.$ cells/mouse $)$ in $0.2 \mathrm{ml}$ mixture of the base media with $50 \%$ matrigel to promote tumour growth. The animals were randomly divided into three groups with eight in each group as follows: a vehicle control group (10\% DMSO + 90\% PEG400), an IBL-302 group $(50 \mathrm{mg} / \mathrm{kg})(10 \% \mathrm{DMSO}+90 \%$ PEG400) and an IBL-302 group in a new formulation ${ }^{1}(10 \%$ DMSO $+70 \%$ PEG400 $+20 \%$ Vitamin E). Each of the groups was orally gavaged for the full 24 days at $(50 \mathrm{mg} / \mathrm{kg} / \mathrm{day})$. The tumour size was measured three times a week, in two dimensions using a calliper and the volume expressed in $\mathrm{mm}^{3}$. The tumour volume was calculated using the formula: $V=$ $\left(0.5 \times A \times B^{2}\right)$ where $A$ and $B$ were the long and short diameters of the tumour, respectively. The tumour size was then used for calculating tumour growth inhibition values. The mice were sacrificed at the end of the experiment and fresh tumour tissues were collected.

\section{Western blot analysis of xBT474 tumours}

Western blot analysis was also performed on tumour samples obtained from xenograft in vivo models of BT-474 (xBT474). xBT474 (xenograft BT-474 tumour cells) mice were harvested at the end of the treatment, 8 and $24 \mathrm{~h}$ post the last dose with BKM120 (35 mg/kg) and IBL-302 $(50 \mathrm{mg} / \mathrm{kg})$. The tumour cells were treated and then lysed

\footnotetext{
${ }^{1}$ New Formulation guideline: The animals in HCC-1954 IBL-302 group with new formulation, dosed down to $35 \mathrm{mg} / \mathrm{kg}$ on D8-D10; mice stopped dosing on D11; mice dosed down to $25 \mathrm{mg} / \mathrm{kg}$ on D12-D13; mice dosed down to $10 \mathrm{mg} / \mathrm{kg}$ on D14-D20; mice were adjusted to $15 \mathrm{mg} / \mathrm{kg}$ on D21-D24 when bodyweight recovered to the baseline.
} 
with $1 \times$ complete lysis buffer for 15 min at $4{ }^{\circ} \mathrm{C}$, and the lysate was then centrifuged at $13,000 \mathrm{rpm}$ for $20 \mathrm{~min}$ at $4{ }^{\circ} \mathrm{C}$. Supernatant was collected and protein quantified using a BCA assay. A total of $20 \mu \mathrm{g}$ of sample per lane was loaded to a NuPAGE Novex $4-12 \%$ Bis-Tris protein gel and resolved. The protein was then transferred using the Invitrogen iBlot 2 gel transfer device and the nitrocellulose transfer stacks. The membrane was blocked for $1 \mathrm{~h}$ in $5 \%$ BSA at room temperature. The membrane was then incubated in primary antibodies (pAKT-(S473) (CST, Cat No. 4060), pBAD-(S112) (CST, Cat No. 5284) and PIM 1 (CST, Cat No. 2907) at 1:1000 dilution) and (GAPDH (Millipore, Cat No. MAB374) 1:5000) overnight at $4{ }^{\circ} \mathrm{C}$. The membrane was then washed thrice and incubated with secondary antibodies (1:10,000 dilution) for $1 \mathrm{~h}$ at room temperature. Image was captured on Li-Cor Odyssey imager and proteins were quantified.

\section{Statistical analysis}

$\mathrm{GI}_{50}$ and effective dose $\left(\mathrm{ED}_{50}\right)$ were calculated using CalcuSyn software (Biosoft). A students' two-tailed $t$ test was used to compare the difference between TNBC and HER2+/ER + groups when stratifying using the $\mathrm{GI}_{50}$ value. A students' two-tailed $t$ test was also used to compare Basal $A$ and Basal $B$ subtypes of TNBC in terms of the $\mathrm{GI}_{50}$ value. A two-way ANOVA, with a post hoc test and $p$-values adjusted using Tukey's honest significant difference, was employed to determine whether the combination of IBL-302 and trastuzumab is more effective at reducing proliferation rates, when compared with either single therapeutic alone (Fig. 5).

Acknowledgements We are very grateful to Stephen Madden for his valuable input and statistical analysis. This research was supported by the North East Cancer Research \& Education Trust, Fox and Kerins families and Enterprise Ireland (Voucher ID: IV-2017-2125).

\section{Compliance with ethical standards}

Conflict of interest MON and DC were shareholders and employees in Inflection Biosciences Ltd. The authors declare that they have no conflict of interest.

Publisher's note Springer Nature remains neutral with regard to jurisdictional claims in published maps and institutional affiliations.

Open Access This article is licensed under a Creative Commons Attribution 4.0 International License, which permits use, sharing, adaptation, distribution and reproduction in any medium or format, as long as you give appropriate credit to the original author(s) and the source, provide a link to the Creative Commons license, and indicate if changes were made. The images or other third party material in this article are included in the article's Creative Commons license, unless indicated otherwise in a credit line to the material. If material is not included in the article's Creative Commons license and your intended use is not permitted by statutory regulation or exceeds the permitted use, you will need to obtain permission directly from the copyright holder. To view a copy of this license, visit http://creativecommons. org/licenses/by/4.0/.

\section{References}

1. Bachmann M, Möröy T, The serine/threonine kinase Pim-1. Int J Biochem Cell Biol. 2005;37:726-30.

2. Tursynbay Y, Zhang J, Li Z, Tokay T, Zhumadilov Z, Wu D, et al. Pim-1 kinase as cancer drug target: an update. Biomed Rep. 2016;4:140-6.

3. Aziz AUR, Farid S, Qin K, Wang H, Liu B. Pim kinases and their relevance to the PI3K/AKT/mTOR pathway in the regulation of ovarian cancer. Biomolecules. 2018;8:7.

4. Nawijn MC, Alendar A, Berns A. For better or for worse: the role of Pim oncogenes in tumorigenesis. Nat Rev Cancer. 2011;11:23-34.

5. Zhao B, Liu L, Mao J, Zhang Z, Wang Q, Li Q. PIM1 mediates epithelial-mesenchymal transition by targeting Smads and c-Myc in the nucleus and potentiates clear-cell renal-cell carcinoma oncogenesis article. Cell Death Dis. 2018;9:307-21.

6. Beier UH, Weise JB, Laudien M, Sauerwein H, Görögh T. Overexpression of Pim-1 in head and neck squamous cell carcinomas. Int J Oncol. 2007;30:1381-7.

7. Roh M, Gary B, Song C, Said-Al-Naief N, Tousson A, Kraft A, et al. Overexpression of the oncogenic kinase Pim-1 leads to genomic instability. Cancer Res. 2003;63:8079-84.

8. Narlik-Grassow M, Blanco-Aparicio C, Carnero A. The PIM family of serine/threonine kinases in cancer. Med Res Rev. 2014;34:136-59.

9. Warfel NA, Kraft AS. PIM kinase (and Akt) biology and signaling in tumors. Pharm Ther. 2015;151:41-9.

10. White E. The pims and outs of survival signaling: role for the Pim2 protein kinase in the suppression of apoptosis by cytokines. Genes Dev. 2003;17:1813-6.

11. Isaac M, Siu A, Jongstra J. The oncogenic PIM kinase family regulates drug resistance through multiple mechanisms. Drug Resist Updates. 2011;14:203-11.

12. Brasó-Maristany F, Filosto S, Catchpole S, Marlow R, Quist J, Francesch-Domenech E, et al. PIM1 kinase regulates cell death, tumor growth and chemotherapy response in triple-negative breast cancer. Nat Med. 2016;22:1303-13.

13. Malinen M, Jääskeläinen T, Pelkonen M, Heikkinen S, Väisänen $\mathrm{S}$, Kosma VM, et al. Proto-oncogene PIM-1 is a novel estrogen receptor target associating with high grade breast tumors. Mol Cell Endocrinol. 2013;365:270-6.

14. Horiuchi D, Camarda R, Zhou AY, Yau C, Momcilovic O, Balakrishnan S, et al. PIM1 kinase inhibition as a targeted therapy against triple-negative breast tumors with elevated MYC expression. Nat Med. 2016;22:1321-9.

15. Rebello RJ, Huglo AV, Furic L. PIM activity in tumours: a key node of therapy resistance. Adv Biol Regul. 2018;67:163-9.

16. Wong PM, Feng Y, Wang J, Shi R, Jiang X. Regulation of autophagy by coordinated action of mTORC1 and protein phosphatase 2A. Nat Commun. 2015;6:8048.

17. Elster N, Cremona M, Morgan C, Toomey S, Carr A, O’Grady A, et al. A preclinical evaluation of the PI3K alpha/delta dominant inhibitor BAY 80-6946 in HER2-positive breast cancer models with acquired resistance to the HER2-targeted therapies trastuzumab and lapatinib. Breast Cancer Res Treat. 2015;149:373-83.

18. Le X, Antony R, Razavi P, Treacy DJ, Luo F, Ghandi M, et al. Systematic functional characterization of resistance to PI3K inhibition in breast cancer. Cancer Discov. 2016;6:1134-47. 
19. Zhang F, Beharry ZM, Harris TE, Lilly MB, Smith CD, Mahajan $\mathrm{S}$, et al. PIM1 protein kinase regulates PRAS40 phosphorylation and mTOR activity in FDCP1 cells. Cancer Biol Ther. 2009;8:846-53.

20. Cen B, Mahajan S, Wang W, Kraft AS. Elevation of receptor tyrosine kinases by small molecule AKT inhibitors in prostate cancer is mediated by Pim-1. Cancer Res. 2013;73:3402-11.

21. Koblish H, Li Y long, Shin N, Hall L, Wang Q, Wang K, et al. Preclinical characterization of INCB053914, a novel pan-PIM kinase inhibitor, alone and in combination with anticancer agents, in models of hematologic malignancies. PLoS ONE. 2018;13: e0199108.

22. Cen B, Xiong Y, Song JH, Mahajan S, DuPont R, McEachern K, et al. The Pim-1 protein kinase is an important regulator of MET receptor tyrosine kinase levels and signaling. Mol Cell Biol. 2014;34:2517-32.

23. Xia Z, Knaak C, Ma J, Beharry ZM, McInnes C, Wang W, et al. Synthesis and evaluation of novel inhibitors of Pim-1 and Pim-2 protein kinases. J Med Chem. 2009;52:74-86.

24. Chen LS, Redkar S, Bearss D, Wierda WG, Gandhi V. Pim kinase inhibitor, SGI-1776, induces apoptosis in chronic lymphocytic leukemia cells. Blood. 2009;114:4150-7.

25. Haddach M, Michaux J, Schwaebe MK, Pierre F, O'Brien SE, Borsan C, et al. Discovery of CX-6258. A potent, selective, and orally efficacious pan-pim kinases inhibitor. ACS Med Chem Lett. 2012;3:135-9.

26. Keeton EK, McEachern K, Dillman KS, Palakurthi S, Cao Y, Grondine MR, et al. AZD1208, a potent and selective pan-Pim kinase inhibitor, demonstrates efficacy in preclinical models of acute myeloid leukemia. Blood. 2014;123:905-13.

27. Garcia PD, Langowski JL, Wang Y, Chen M, Castillo J, Fanton C, et al. Pan-PIM kinase inhibition provides a novel therapy for treating hematologic cancers. Clin Cancer Res. 2014;20:1834-45.

28. Burger MT, Nishiguchi G, Han W, Lan J, Simmons R, Atallah G, et al. Identification of N-(4-((1R,3S,5S)-3-amino-5-methylcyclohexyl)pyridin-3-yl)-6-(2,6-difluorophenyl)-5-fluoropicolinamide (PIM447), a potent and selective proviral insertion site of Moloney murine leukemia (PIM) 1, 2, and 3 kinase inhibitor in clinical tria. J Med Chem. 2015;58:8373-86.

29. Païno T, Garcia-Gomez A, González-Méndez L, San-Segundo L, Hernández-García S, López-Iglesias AA, et al. The novel pan-PIM kinase inhibitor, PIM447, displays dual antimyeloma and boneprotective effects, and potently synergizes with current standards of care. Clin. Cancer Res. 2017;23:225-38.

30. Cortes J, Tamura K, Deangelo DJ, De Bono J, Lorente D, Minden M, et al. Phase I studies of AZD1208, a proviral integration Moloney virus kinase inhibitor in solid and haematological cancers. Br J Cancer. 2018;118:1425-33.

31. Dakin LA, Block MH, Chen H, Code E, Dowling JE, Feng X, et al. Discovery of novel benzylidene-1,3-thiazolidine-2,4-diones as potent and selective inhibitors of the PIM-1, PIM-2, and PIM-3 protein kinases. Bioorg Med Chem Lett. 2012;22:4599-604.

32. Meja K, Stengel C, Sellar R, Huszar D, Davies BR, Gale RE, et al. PIM and AKT kinase inhibitors show synergistic cytotoxicity in acute myeloid leukaemia that is associated with convergence on mTOR and MCL1 pathways. Br J Haematol. 2014;167:69-79.

33. Neil M, Aparicio CB, Jiang S, Martinez S, McKenzie A, Page M, et al. Abstract 4524: Combined inhibition of PIM and PI3 kinases shows an enhanced efficacy in a number of solid tumour cell lines. Cancer Res. 2014;74:4524.

34. Moore G, Heavey S, Lightner C, Brady L, O'Byrne K, Finn S, et al. P1.02-065 elucidating the role of PIM kinase and its therapeutic potential in NSCLC. J Thorac Oncol. 2017;12:S527-8. https://doi.org/10.1016/j.jtho.2016.11.649.

35. Reidy $M$, et al. Initial evaluation of novel dual PIM/PI3K and triple PIM/PI3K/mTOR inhibitors in multiple myeloma. Blood.
2014;124:5713. LP-5713. http://www.bloodjournal.org/content/ 124/21/5713.abstract.

36. Moody SE, Schinzel AC, Singh S, Izzo F, Strickland MR, Luo L, et al. PRKACA mediates resistance to HER2-targeted therapy in breast cancer cells and restores anti-apoptotic signaling. Oncogene. 2014;34:2061-71.

37. Bian C, Liu Z, Li D, Zhen L. PI3K/AKT inhibition induces compensatory activation of the MET/STAT3 pathway in nonsmall cell lung cancer. Oncol Lett. 2018;15:9655-62.

38. Sourbier C, Lindner V, Lang H, Agouni A, Schordan E, Danilin S, et al. The phosphoinositide 3-kinase/Akt pathway: A new target in human renal cell carcinoma therapy. Cancer Res. 2006;66:5130-42.

39. Simioni C, Cani A, Martelli AM, Zauli G, Tabellini G, McCubrey $\mathrm{J}$, et al. Activity of the novel mTOR inhibitor Torin-2 in Bprecursor acute lymphoblastic leukemia and its therapeutic potential to prevent Akt reactivation. Oncotarget. 2014; 5:10034-47.

40. Herzog A, Bian Y, Vander BroekR, Hall B, Coupar J, Cheng H, et al. PI3K/mTOR inhibitor PF-04691502 antitumor activity is enhanced with induction of wild-type TP53 in human xenograft and murine knockout models of head and neck cancer. Clin Cancer Res. 2013;19:3808-19.

41. Hua H, Zhu Y, Song YH. Ruscogenin suppressed the hepatocellular carcinoma metastasis via PI3K/Akt/mTOR signaling pathway. Biomed Pharmacother. 2018;101:115-22.

42. Chapuis N, Tamburini J, Green AS, Vignon C, Bardet V, Neyret $\mathrm{A}$, et al. Dual inhibition of PI3K and mTORC1/2 signaling by NVP-BEZ235 as a new therapeutic strategy for acute myeloid leukemia. Clin Cancer Res. 2010;16:5424-35.

43. Macdonald A, Campbell DG, Toth R, McLauchlan H, Hastie CJ, Arthur JSC. Pim kinases phosphorylate multiple sites in Bad and promote 14-3-3 binding and dissociation from Bcl-XL. BMC Cell Biol. 2006;7:1.

44. Bhattacharya N, Wang Z, Davitt C, McKenzie IFC, Xing PX, Magnuson NS. Pim-1 associates with protein complexes necessary for mitosis. Chromosoma. 2002;111:80-95.

45. Wang Z, Bhattacharya N, Mixter PF, Wei W, Sedivy J, Magnuson NS. Phosphorylation of the cell cycle inhibitor p21Cip1/WAF1by Pim-1 kinase. Biochim Biophys Acta. 2002;1593:45-55.

46. Zhang Y, Wang Z, Magnuson NS. Pim-1 kinase-dependent phosphorylation of p21Cip1/WAF1 regulates its stability and cellular localization in $\mathrm{H} 1299$ cells. Mol Cancer Res. 2007;5:909-22.

47. Jin B, Wang Y, Wu CL, Liu KY, Chen H, Mao Z Bin. PIM-1 modulates cellular senescence and links IL-6 signaling to heterochromatin formation. Aging Cell. 2014;13:879-89.

48. Yang J, Liu K, Yang J, Jin B, Chen H, Zhan X, et al. PIM1 induces cellular senescence through phosphorylation of UHRF1 at Ser311. Oncogene. 2017;36:4828-42.

49. Hogan C, Hutchison C, Marcar L, Milne D, Saville M, Goodlad J, et al. Elevated levels of oncogenic protein kinase Pim-1 induce the p53 pathway in cultured cells and correlate with increased Mdm2 in mantle cell lymphoma. J Biol Chem. 2008;283:18012-23.

50. Mohlin S, Hansson K, Radke K, Martinez S, Blanco-Apiricio C, Garcia-Ruiz C, et al. Anti-tumor effects of PIM / PI 3K/ mTOR triple kinase inhibitor IBL -302 in neuroblastoma. EMBO Mol Med. 2019;11:10058.

51. Cobb M, Hunter L, Carlson D, Darr D, Haystead T, Baines AT. Abstract 524: Characterizing the in-vitro and in-vivo effects of the PIM kinase inhibitor HS140 in triple-negative human breast cancer. Cancer Res. 2017;77:524.

52. Liu WT, Jing YY, Yu GF, Chen H, Han ZP, Yu DD, et al. Hepatic stellate cell promoted hepatoma cell invasion via the HGF/c-Met signaling pathway regulated by p53. Cell Cycle. 2016;15:886-94.

53. Zhang R, Zhou Z, Lu S, Lu Z, Wan D, Pan Z, et al. Pim-3 as a potential predictor of chemoradiotherapy resistance in locally 
advanced rectal cancer patients. Sci Rep Am Soc Clin Oncol. 2017;7:16043.

54. Chandarlapaty S, Sawai A, Scaltriti M, Rodrik-Outmezguine V, Grbovic-Huezo O, Serra V, et al. AKT inhibition relieves feedback suppression of receptor tyrosine kinase expression and activity. Cancer Cell. 2011;19:58-71.

55. Liu P, Cheng H, Santiago S, Raeder M, Zhang F, Isabella A, et al. Oncogenic PIK3CA-driven mammary tumors frequently recur via PI3K pathway-dependent and PI3K pathway-independent mechanisms. Nat Med. 2011;17:1116-20.

56. Ilic N, Utermark T, Widlund HR, Roberts TM. PI3K-targeted therapy can be evaded by gene amplification along the MYCeukaryotic translation initiation factor 4E (eIF4E) axis. Proc Natl Acad Sci. 2011;108:E699-708.

57. Doshi KA, Natarajan K, Wolfson B, Huszar D, Baer MR. The Pim kinase inhibitor AZD1208 sensitizes acute myeloid leukemia cells with fms-like tyrosine kinase 3 internal tandem duplication (FLT3-ITD) to cytotoxic effects of chemotherapy drugs. Cancer Res. 2015;75:5332.

58. Song JH, Kraft AS. Pim kinase inhibitors sensitize prostate cancer cells to apoptosis triggered by Bcl-2 family inhibitor ABT-737. Cancer Res. 2012;72:294-303.

59. Musiani D, Hammond DE, Cirillo L, Erriquez J, Olivero M, Clague MJ, et al. PIM2 kinase is induced by cisplatin in ovarian cancer cells and limits drug efficacy. J Proteome Res. 2014; 13:4970-82.
60. Tursynbay Y, Zhang J, Li Z, Tokay T, Zhumadilov Z, Wu D, et al. Pim-1 kinase as cancer drug target: an update. Biomed Rep. 2016;4:140-6.

61. Keegan NM, Walshe JM, Toomey S, Gullo G, Kennedy MJ, Bulger KN, et al. A phase Ib trial of copanlisib and tratuzumab in pretreated recurrent or metastatic HER2-positive breast cancer "PantHER". J Clin Oncol. 2018;36:1036.

62. Elster N, Toomey S, Fan Y, Cremona M, Morgan C, Weiner Gorzel K. et al. Frequency, impact and a preclinical study of novel ERBB gene family mutations in HER2-positive breast cancer. Ther Adv Med Oncol. 2018;10:1758835918778297. https://doi. org/10.1177/1758835918778297.

63. Rampal RK, Maria P-O, Amritha Varshini HS, Levine RL, Cao A. Synergistic therapeutic efficacy of combined JAK1/2, Pan-PIM, and CDK4/6 inhibition in myeloproliferative neoplasms. Blood.2016;128:634.

64. McDermott MSJ, Browne BC, Conlon NT, O’Brien NA, Slamon DJ, Henry M, et al. PP2A inhibition overcomes acquired resistance to HER2 targeted therapy. Mol Cancer. 2014;13:157.

65. McDermott MSJ, Canonici A, Ivers L, Browne BC, Madden SF, O'Brien NA, et al. Dual inhibition of IGF1R and ER enhances response to trastuzumab in HER2 positive breast cancer cells. Int $\mathbf{J}$ Oncol. 2017;50:2221-8.

66. Eustace AJ, Crown J, Clynes M, O’Donovan N. Preclinical evaluation of dasatinib, a potent Src kinase inhibitor, in melanoma cell lines. J Transl Med. 2008;6:53. 